\title{
Perancangan Media Pembelajaran Berbasis Lectora pada Mata Pelajaran Komputer dan Jaringan Dasar Materi Dasar Komputer kelas X di SMK Muhammadiyah Aimas Kabupaten Sorong
}

\author{
Indri Anugrah Ramadhani, Juanda Rumaur \\ Universitas Pendidikan Muhammadiyah Sorong \\ indianugrah18@gmail.com
}

\begin{abstract}
Abstrak: Tujuan dilakukan penelitian ini adalah untuk merancang media pembelajaran yang menarik berbasis lectora pada mata pelajaran komputer dan jaringan dasar dalam materi dasar komputer yang layak digunakan. Jenis penelitian yang digunakan adalah (research and development/R\&D) dan menggunakan model pengembangan ADDIE, teknik pengumpulan data yang digunakan adalah obseravsi, wawancara, dan dokumentasi. Analisi data yang digunakan yaitu validasi ahli, uji coba kelompok kecil dan uji coba kelompok besar. Hasil penilaian dari uji coba produk/ skala kecil untuk media pembelajaran yang dibuat mendapatkan nilai rata - rata sebesar 81,66 dalam kategori sangat baik hasil penilaian dari uji coba pemakaian/skala besar untuk media pembelajaran yang dibuat mendapatkan nilai rata - rata sebesar 82,70 dalam kategori sangat baik. Sehingga dapat disimpulkan bahwa media pembelajaran Dasar Komputer dengan basis aplikasi Lectora Inspire layak digunakan sebagai media pembelajaran.
\end{abstract}

Kata kunci : media, pembelajaran, lectora, $R \& D$, ADDIE,

\section{Pendahuluan}

Perkembangan ilmu pengetahuan dan teknologi semakin mendorong upaya-upaya pembaharuan dalam pemanfaatan hasil-hasil teknologi dalam proses belajar. Para guru dituntut agar mampu menggunakan alat-alat yang dapat disediakan oleh sekolah, dan tidak tertutup kemungkinan bahwa alat-alat tersebut sesuai dengan perkembangan dan tuntutan zaman. Guru sekurang-kurangnya dapat menggunakan alat yang murah dan efisien yang meskipun sederhana dan bersahaja tetapi merupakan keharusan dalam upaya mencapai tujuan pengajaran yang diharapkan. Disamping mampu menggunakan alat-alat yang tersedia, guru juga dituntut untuk dapat mengembangkan keterampilan membuat media pembelajaran yang akan digunakannya apabila media tersebut belum tersedia. Untuk itu guru harus memiliki pengetahuan dan pemahaman yang cukup tentang media pembelajaran, yang meliputi: (1) Media sebagai alat komunikasi guna lebih mengefektifkan proses belajar mengajar, (2) Fungsi media dalam rangka mencapai tujuan pendidikan, (3) Seluk-beluk proses belajar, (4) Hubungan antara metode mengajar dan media pendidikan, (5) Nilai atau manfaat media pendidikan dalam pengajaran, (6) Pemilihan dan penggunaan media pendidikan, (7) Berbagai jenis alat dan teknik media pendidikan, (8) Media pendidikan dalam setiap mata pelajaran, (9) Usaha inovasi dalam media pendidikan.

Media adalah bagian yang tidak dapat terpisahkan dari proses belajar mengajar demi tercapainya tujuan pendidikan pada umumnya dan tujuan 
pembelajaran di sekolah pada khususnya. Menurut Azhar Arsyad, (2011: 1-2), Media adalah alat bantu apa saja yang dapat dijadikan sebagai penyalur pesan guna mencapai tujuan pembelajaran. Adapaun studi literature yang relevan dengan penelitian ini adalah:

Hasil penelitian oleh Jofan Nugroho F.W.S. dan Wardan Suyanto (2013) dengan judul "Penggunaan Software Lectora Inspire Sebagai Media Pembelajaran untuk Meningkatkan Hasil Belajar Siswa pada Mata Pelajaran Sistem Bahan Bakar Sepeda Motor KeLas X Jurusan Teknik Kendaraan Ringan SMK Perindustrian Yogyakarta" Menunjukkan bahwa ada peningkatan hasil belajar siswa kelas X B1. Hal ini ditunjukan dengan nilai rata-rata hasil belajar siswa dan persentase ketuntasan klasikal kelas sebagai berikut: pada pra-penelitian nilai ratarata siswa adalah 51 dan persentase ketuntasan klasikal kelas 42,1\%. Pada siklus I nilai rata-rata siswa meningkat menjadi 75,8 dan persentase ketuntasan klasikal kelas $83,3 \%$. Pada siklus II nilai rata-rata siswa meningkat menjadi 81,6 dan persentase ketuntasan klasikal kelas $88,9 \%$ sehingga sudah memenuhi kriteria ketuntasan klasikal yang ditentukan oleh sekolah yakni $\geq 85 \%$.

Hasil penelitian oleh Akbar Ramadhan (2014) dengan judul "Pengembangan Media Pembelajaran Menggunakan Multimedia Interaktif Lectora Inspire Pada Mata Pelajaran Teknik Elektronika di SMK Negeri 3 Jombang" menunjukkan bahwa hasil penelitian Perancangan media pembelajaran menggunakan multimedia interaktif lectora inspire yang telah divalidasi dengan hasil rating dari format media sebesar $84,37 \%$, materi media sebesar $81,25 \%$, aspek bahasa sebesar $81,25 \%$, dan pada animasi media sebesar 87,5. Sehingga secara umum media yang dikembangkan dikategorikan sangat baik dengan hasil rating rata-rata $84 \%$. Respon siswa pada keseluruhan aspek yang terdapat didalam media pembelajaran dinyatakan sangat baik dengan rata-rata hasil rating sebesar $86,19 \%$. Hal ini menunjukkan bahwa media pembelajaran yang dihasilkan layak digunakan sebagai media pembelajaran.

Dari hasil wawancara yang dilakukan oleh peneliti pada salah satu guru di SMK Muhammadiyah Aimas (Pak Kartono) yaitu; pada pelajaran dasar komputer banyak materi - materi mengenai proses pengenalan, pelaksanaan dan perancangan. Jika proses, pelaksanaan dan cara disampaikan dengan metode ceramah, atau biasanya dilakukan dengan membawa hardware maka ada kesulitan tersendiri bagi pengajar saat menjelaskan kepada siswanya akan merasa bingung dan kurang menyerap apa yang disampaikan karna tidak semua siswa melihat dalam bentuk hardware tersebut cuman beberapa saja yang melihat dan memperhatikan.

Maka disini peran media pembelajaran khususnya Lectora yang digunakan. Salah satu contoh peran media misalnya dalam kegiatan belajar mengajar yaitu, seorang guru tidak perlu repot-repot membawa semua yang berkaitan dengan materi dasar komputer untuk menjelaskan. Cukup menggunakan gambar atau video yang ditayangkan melalui media Lectora sudah dapat mewakili proses dalam pembelajaran dasar komputer.

Berdasarkan masalah tersebut sebagai peneliti berupaya untuk mengembangkan dan memanfaatkan media yang sudah ada demi tercapainya tujuan pembelajaran di sekolah khususnya kelas $X$ yang mendapatkan pelajaran komputer dan jaringan dasar pada materi yang dasar komputer di SMK Muhammadiyah Aimas Kabupaten Sorong 


\section{Metode Penelitian}

Jenis penelitian yang digunakan adalah Research and Development (R\&D) atau penelitian dan pengembangan dapat diartikan sebagai cara ilmiah untuk meneliti, merancang, memproduksi dan menguji validitas produk yang dihasilkan (Prof.Dr.Sugiyono, 2015) Adapun model pengembangan yang digunakan dalam penelitian pengembangan berbasis Lectora pada mata pelajaran komputer dan jaringan dasar dalam materi komputer dasar adalah model ADDIE. Istilah ADDIE merupakan satu akronim bagi Analysis (analisis), Design (reka bentuk), Development (perkembangan), Implementation (pelaksanaan), dan Evaluation (penilaian) Salah satu fungsi model ADDIE yaitu untuk menjadi pedoman dalam membangun atau mengembangkan suatu perangkat dan berfungsi sebagai program pelatihan yang bersifat dinamis dan efektif.

Teknik analisis data yang digunakan adalah (1) Pedoman Wawancara yang dilakukan kepada guru Mata Pelajaran Komputer dan Jaringan Dasar dalam Materi Dasar Komputer di SMK Muhammadiyah Aimas wawancara digunakan sebagai teknik pengumpulan data ketika peneliti melakukan studi pendahuluan untuk menemukan permasalahan yang harus diteliti, dan ingin mengetahui hal-hal dari responden yang mendalam. (2) Angket adalah sejumlah pertanyaan tertulis yang digunakan untuk memperoleh informasi dari responden Instrumen yang digunakan untuk mengumpulkan data penelitian ini adalah berupa angket yang terdiri dari dua bagian. Bagian pertama merupakan instrumen pengumpulan data kuantitatif yaitu berupa angket dengan berbasis skala Likert dengan alternatif multiple choice

\section{Hasil dan Pembahasan}

Produk yang dihasilkan dari penelitian pengembangan ini adalah media pembelajaran Dasar komputer dengan Basis aplikasi Lectora. Media pembelajaran ini dapat dikemas dalam bentuk CD interaktif atau dapat disebarluaskan melalui flashdisc dengan kapasitas memori tidak lebih 200 MB. Media pembelajaran Dasar komputer ini dapat digunakan sebagai media pembelajaran dalam penyampaian materi di kelas maupun sebagai media pembelajaran mandiri bagi siswa.

Desain tampilan halaman dapan yang bisa kita liat pada Gambar 1 dari media pembelajaran ini terdiri dari logo UNIMUDA, tulisan UNIMUDA, serta tulisan media pembelajaran pada bagian atas tampilan. Pada bagian bawahnya terdapat tombol untuk mengakses menu utama. Bagian bawah kiri terdapat gambar. Kemudian di bagian sebelah gambar terdapat tulisan penjelasan mengenai kompetensi dasar serta tujuan pembelajaran yang ingin dicapai.

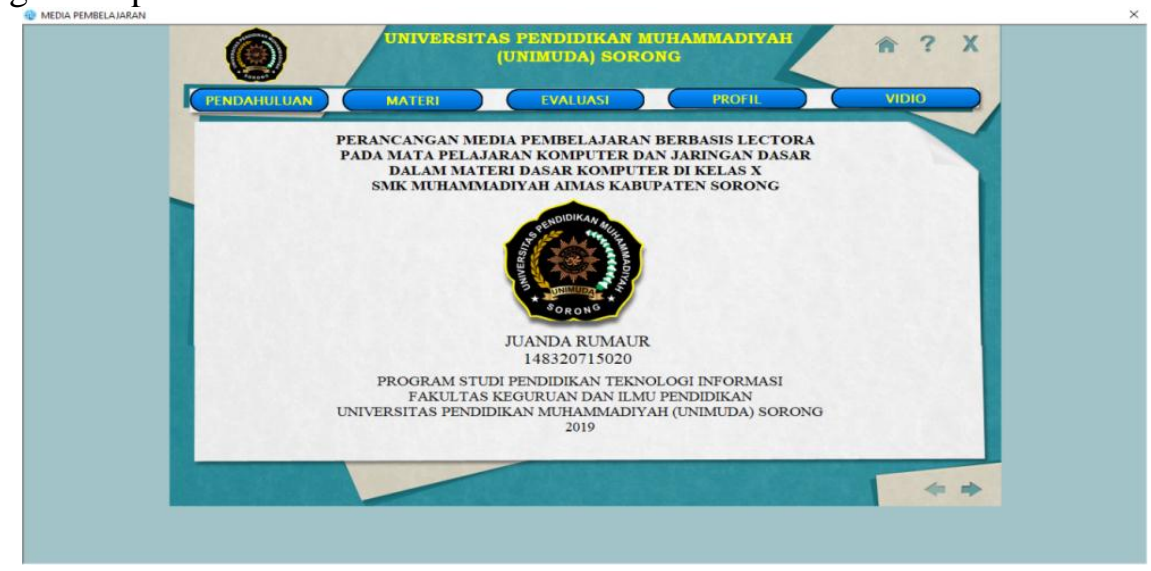

Gambar 1. Halaman Depan/Cover 
Desain tampilan halaman dapan yang bisa kita liat pada gambar 2 dari media pembelajaran ini terdiri dari logo UNIMUDA, tulisan UNIMUDA, serta tulisan media pembelajaran pada bagian atas tampilan. Pada bagian bawahnya terdapat tombol untuk mengakses menu utama. Bagian bawah kiri terdapat gambar. Kemudian di bagian sebelah gambar terdapat tulisan penjelasan mengenai kompetensi dasar.

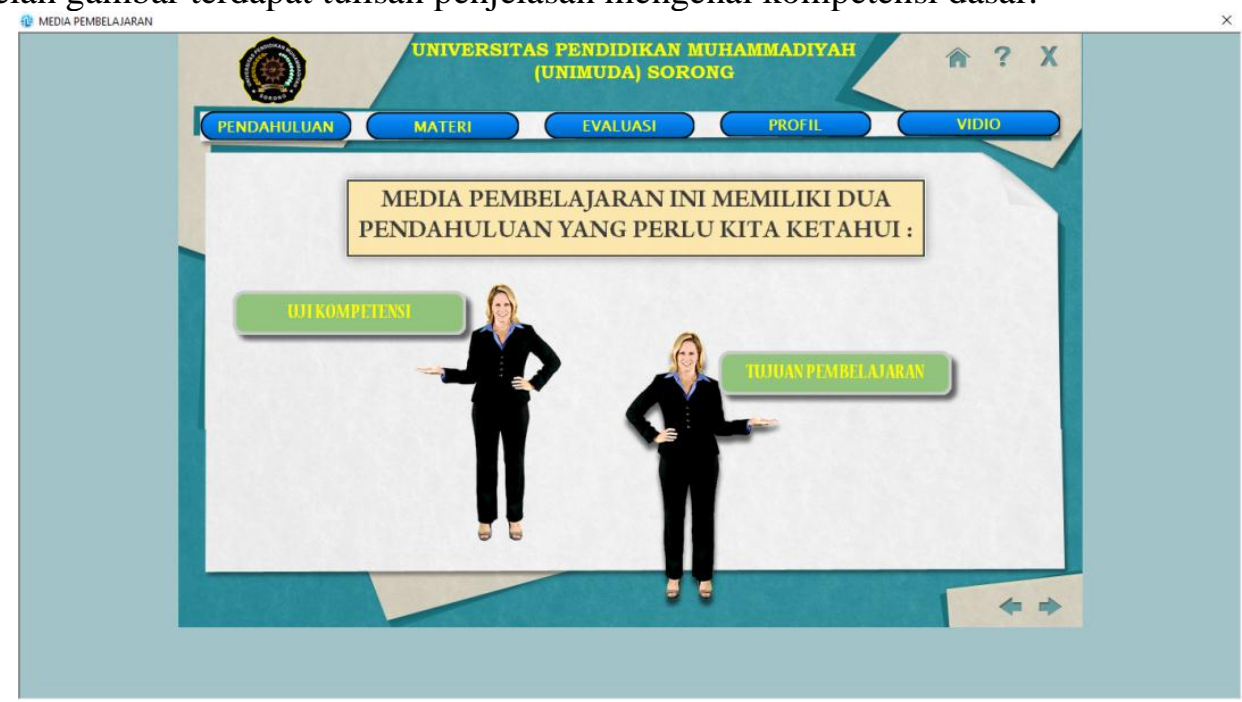

Gambar 2. Tampilan Uji Halaman Pendahuluan

Desain tampilan menu materi dari media pembelajaran ini terdiri dari logo UNIMUDA, tulisan UNIMUDA, serta tulisan media pembelajaran pada bagian atas tampilan. Pada bagian bawahnya terdapat tombol untuk mengakses menu utama. Bagian bawah kiri terdapat tombol untuk mengakses materi yang disajikan dalam media. Kemudian di bagian sebelah tombol terdapat tampilan mengenai materi yang disajikan dengan unsur gambar, atau animasi, judul materi, serta penjelasan mengenai materi yang bearada didalamnya. Dapat kita lihat pada Gambar 3.

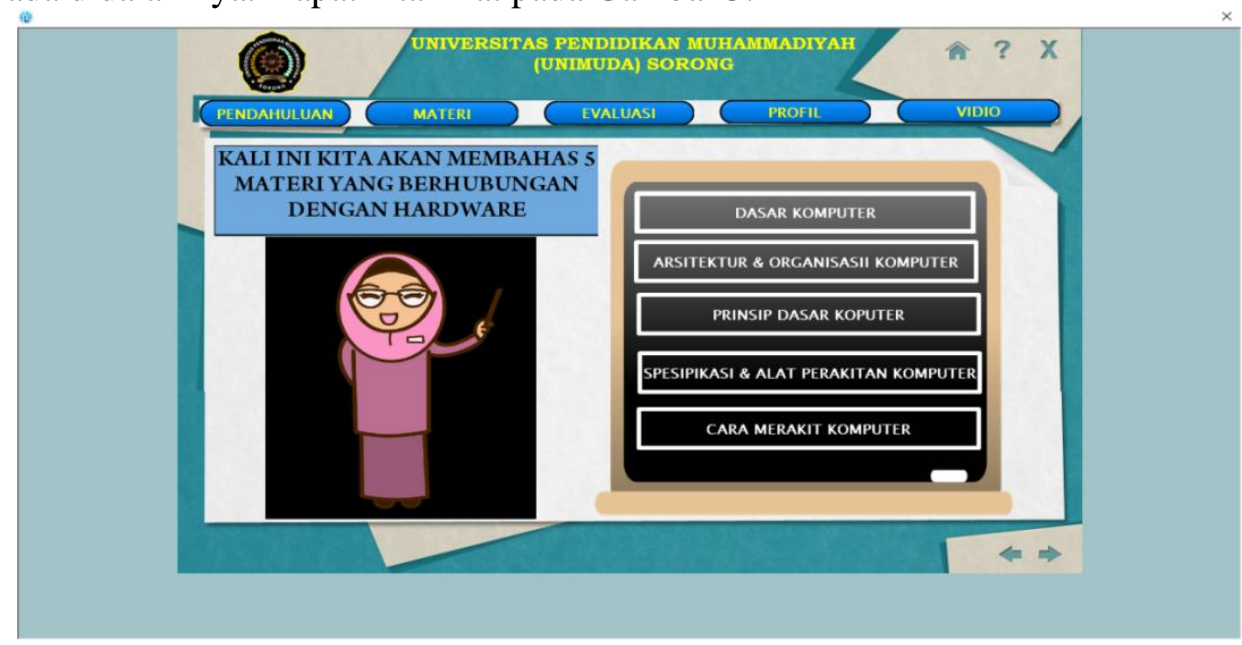

Gambar 3. Tampilan Halaman Materi 
Desain tampilan evaluasi dari media pembelajaran ini terdiri dari logo UNIMUDA, tulisan UNIMUDA, Pada bagian atas kiri terdapat tombol untuk mengakses menu utama. Bagian bawah kiri terdapat tampilan sukses jika jawaban benar bisa kita liat pada Gambar 4.

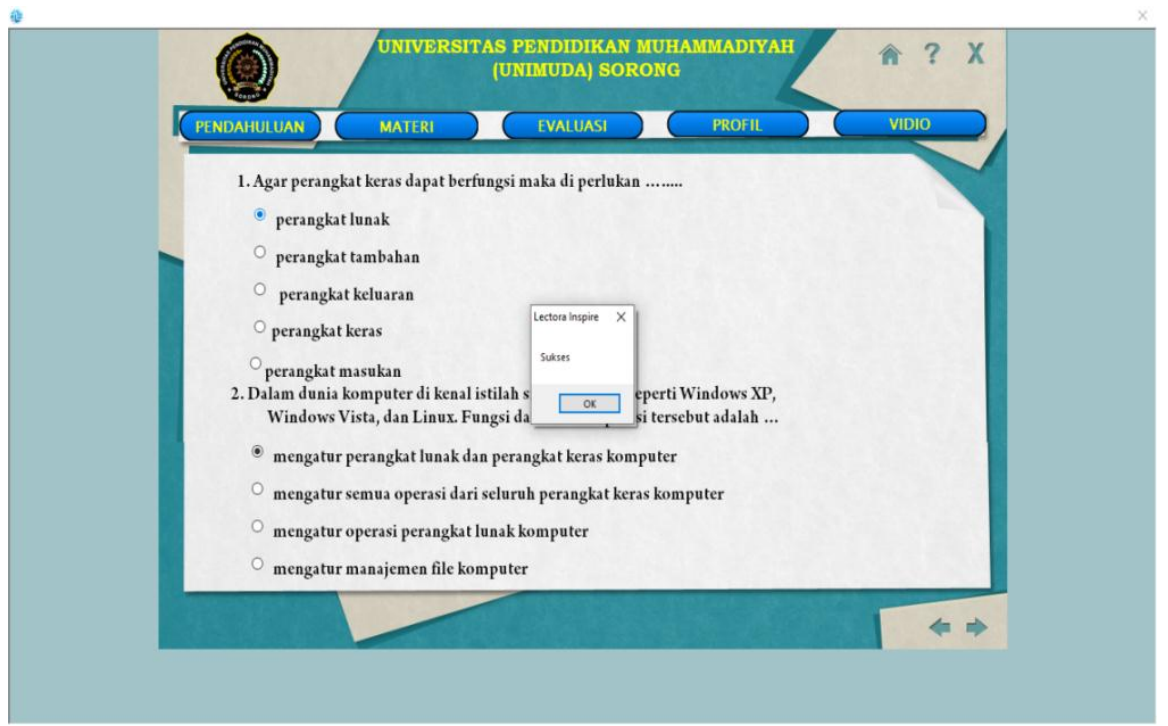

Gambar 4. Tampilan Halaman Evaluasi

Hasil ujicoba pemakaian meliputi: (1) aspek manfaat media, (2) peenyampaian materi, (3) silabus, (4) desain media, serta (5) pengoperasian media. Dari hasil uji coba pemakaian, data yang diperoleh diharapkan dapat menggambarkan penilaian pengguna terhadap media pembelajaran. Hasil penilaian dari uji coba pemakaian disajikan dalam Tebel 1

Tabel 1 Tabel Uji Coba Pemakaian

\begin{tabular}{|c|l|c|c|c|}
\hline Skala Kecil & \multicolumn{1}{|c|}{ Indikator } & Nilai & Rata - Rata & Kategori \\
\hline \multirow{4}{*}{$\begin{array}{c}\text { Uji Produk } \\
\text { Media } \\
\text { Pemebelajaran }\end{array}$} & Manfaat Media & 213 & $88,75 \%$ & Sangat Baik \\
\cline { 2 - 5 } & Penyampaian Materi & 204 & $85 \%$ & Sangat Baik \\
\cline { 2 - 5 } & Silabus & 144 & $90 \%$ & Sangat Baik \\
\cline { 2 - 5 } & Desain Media & 424 & $88,33 \%$ & Sangat Baik \\
\cline { 2 - 5 } & Pengoperasian Media & 206 & $85 \%$ & Sangat Baik \\
\hline \multicolumn{2}{|c|}{ Jumlah } & $\mathbf{1 , 1 9 1}$ & $\mathbf{8 2 , 7 0 \%}$ & Sangat Baik \\
\hline
\end{tabular}

Berdasarkan data dari tabel hasil uji coba pemakaian, total penilaian dalam uji coba pemakaian terhadap media pembelajaran sebesar $82,70 \%$ dan dikategorikan "Sangat Baik" digunakan sebagai media pembelajaran.

Hasil dari pengamatan terhadap 20 responden uji coba pemakaian/skala besar selama kegiatan pemaparan hasil produk media pembelajaran berlangsung, didapatkan data bahwa semua responden atau sejumlah 20 responden memperhatikan serta fokus kepada penjelasan tentang materi dasar komputer menggunakan media pembelajaran yang dihasilkan. Berdasarkan penjelasan tersebut, dapat disimpulkan bahwa media pembelajaran Dasar komputer berbasis aplikasi Lectora Inspire dapat menarik perhatian siswa. Siswa menjadi lebih fokus dalam memperhatikan penjelasan guru. Kegiatan belajar mengajar dapat berjalan dengan lancar serta baik bila ditinjau dari segi antusiasme siswa. 


\section{Kesimpulan dan Saran}

Perancangan Media pembelajaran berbasis Lectora pada mata pelajaran komputer dan jaringan dasar materi komputer adalah (1) pembuatan cover atau halaman depan media pembelajaran (2) pendahuluan yang terdiri dari uji kopetensi dan tujuan pembelajaran dalam media (3) Materi pembelajaran yang terdiri dari herdware, Software, Brainware (4) Evaluasi Materi pemeblajaran (5) profil peneliti dan pembimbing, untuk menghasilkan media pembelajaran Dasar Komputer dengan basis aplikasi Lectora Inspire. Perlunya tahapan yaitu (1) potensi dan masalah, (2) Pengumpulan data,(3) Desain produk,(4) Validasi desain,(5) Uji coba produk, (6) Uji coba pemakaian, (7) Produksi massal.

Hasil penilaian dari uji coba produk untuk media pembelajaran yang dibuat mendapatkan nilai rata - rata sebesar 81,66 dalam kategori sangat baik hasil penilaian dari uji coba pemakaian/skala besar untuk media pembelajaran yang dibuat mendapatkan nilai rata - rata sebesar 82,70 dalam kategori sangat baik. Sehingga dapat disimpulkan bahwa media pembelajaran Dasar Komputer dengan basis aplikasi Lectora Inspire layak digunakan sebagai media pembelajaran.

\section{Daftar Pustaka}

Arief S. Sadiman Et.al. (2009). Media Pendidikan: Pengertian,Pengembangan dan Pemanfaatannya. Jakarta: PT. Raja Grafindo Persada.

Arief S. Sadiman. (1993). Media Pendidikan, Jakarta:PT. Raja Grafindo Persada. Azhar Arsyad. (2013). Media Pembelajaran, ed.rev. Jakarta: PT. Raja Grafindo Persada.

BTKP DIY. (t.t.). Modul Pengenalan Lectora Authoring Tool, Yogyakarta: BTKP DIY.

Deny Darmawan. (2012). Inovasi Pendidikan, Bandung : PT. Remaja Rosdakarya.

Direktorat Pembinaan Sekolah Menengah Kejuruan. (t.t.). Modul Sistem Kelistrikan dan Elektronika pada Kendaraan, : Direktorat Pembinaan Sekolah Menengah Kejuruan.

Ena Kharismaya. (2011). Pengembangan Media Pembelajaran Interaktif Pada Mata Pelajaran Ketereampilan Dan Pengelolaan Informasi Di SMK N 2 Depok Sleman Yogyakarta. Laporan Skripsi. UNY.

Eveline Siregar dan Hartini Nara. (2010). Teori Belajar dan Pembelajaran, Bogor : PT. Ghalia Indonesia.

Hajah Ukhti Zumara. (2012). Modul Media Pembelajaran, Bandung : Universitas Pendidikan Indonesia.

Haris Mudjiman. (2007). Belajar Mandiri, Surakarta : UNS PRESS. Harjanto. (2011). Perencanaan Pengajaran, Jakarta : PT.

Rineka Cipta.

Joesolo. (2013). Lectora Portable : Aplikasi Media Pembelajaran Interaktif. Diakses dari http://surakartahadiningrat.com/2013/04/membangunpembelajaran-interaktif/ Pada 04 Desember 2014, jam 10.52 WIB.

Latuheru, John D. (1988). Media Pembelajaran,Jakarta : Departemen Pendidikan Nasional. 
Nana Sudjana. (2004). Dasar - Dasar Proses Belajar Mengajar, Bandung : Sinar Baru Algesindo.

Nana S. Sukmadinata. (2009).Metode Penelitian Pendidikan, Bandung : PT.

Remaja Rosdakarya Offset.

Sharon E. Smaldino, Deborah L. Lowther, Jamess D. Russel. (2011). Instructional Technology and Media for Learning. Jakarta : Kencana Pemuda Media Group

Sugiyono. (2012). Metode Penelitian Pendidikan, Bandung : CV.Alfabeta.

Suharsimi Arikunto. (2010). Prosedur Penelitian, Jakarta : PT.

Rineka Cipta. Sukardjo. (2006). Kumpulan Materi Evaluasi, Yogyakarta : UNY.

Rudi Susilana dan Cepi Riyana. (2008). Media Pembelajaran, Bandung : Jurusan KURTEKPEND FIP UPI.

Yudhi Munandi. (2013). Media Pembelajaran Sebuah Pendekatan Baru, Jakarta Selatan : Referensi.

Yusuf Hadi Miarso. (2004). Menyemai Benih Teknologi Pendidikan, Jakarta: Prenada Media dan Pustekkom Diknas.

Yusuf Hadi Miarso dkk. (1984). Teknologi Komunikasi Pendidikan, Jakarta : CV. Rajawali. 